\title{
Resistance to metal ions and antibiotics in Escherichia coli isolated from foodstuffs
}

\author{
J. S. GREWAL and R. P. TIWARI*
}

Department of Microbiology, Basic Medical Sciences Building, Panjab University, Chandigarh, India

\begin{abstract}
Summary. Of 39 strains of Escherichia coli isolated from foodstuffs, all were resistant to at least one of a panel of four metallic ions tested. The most common resistance $(94.9 \%)$ was against cadmium, followed by arsenate $(76.9 \%)$, silver $(71.8 \%)$ and mercury $(61 \cdot 5 \%)$. Multiple resistance to three $(35.9 \%)$ or four $(38.5 \%)$ metals was seen more often than resistance to two $(18 \%)$ or one $(7.7 \%)$ metal only. The opposite trend was seen in antibiotic resistance; resistance to one $(30 \%)$ or two $(49 \%)$ antibiotics was more common than to three or more antibiotics $(13 \%)$. Resistance to kanamycin correlated with resistance to silver and cadmium ions and resistance to ampicillin or cephalothin was, with one exception, associated with resistance to cadmium ions.
\end{abstract}

\section{Introduction}

Gram-negative bacteria are considered generally to be more resistant than gram-positive bacteria to antimicrobial agents (Hugo and Russell, 1982; Russell, 1982). The transfer of multiple drug resistance through $\mathrm{R}$ factors has long been recognised in the enterobacteria, especially Escherichia coli (Anderson, 1965; Linton et al., 1981). The plasmids of $E$. coli not only confer resistance to antibiotics and metal ions (Efstathiou and McKay, 1977; Foster et al., 1979; Chopra, 1982; Foster, 1983; Starodub and Trevors, 1989) but, in a few reports, have even been shown to confer sensitivity to mercuric chloride and antibiotics (Foster et al., 1979; Platt et al., 1984). Specific serotypes of $E$. coli have been shown to carry transmissible plasmids for both enterotoxin production $\left(\mathrm{Ent}^{+}\right)$and resistance (R) to antibiotics (Walton, 1977; Echeverria and Murphy, 1980). The occurrence of antibiotic resistant $E$. coli in man, sewage and fresh water has been reported (Grabow et al., 1975; Meckes, 1982; Towner, 1982; Antai, 1987).

This study is of the resistance, in $E$. coli strains isolated from foodstuffs, to four heavy metals and 12 antibiotics. Foods containing $E$. coli have often been implicated in specific and non-specific diarrhoea in children (Linton and Hinton, 1988), travellers' diarrhoea (Lee and Kean, 1978) and severe cholera-like illness (Sack et al., 1971). We have attempted to correlate the metal ion and antibiotic resistance in $E$. coli isolates from food.

Received 18 Dec. 1989; accepted 29 Dec. 1989.

- Correspondence should be sent to Dr R. P. Tiwari.

\section{Materials and methods}

\section{E. coli strains}

Food samples (ice cream, curd, sweets, raw milk and rasmalai) were collected in sterile containers from approved shops in Chandigarh, India. The samples were transported to the laboratory and plated on to MacConkey's agar, within 1-2 $\mathrm{h}$ of sampling, for the isolation of E. coli. The isolates were identified by standard biochemical tests (Ørskov, 1984).

\section{Media and chemicals}

Culture media were obtained from Hi-Media Laboratories, Bombay, India. Reagent grade metal salts (silver nitrate, cadmium sulphate, mercuric chloride and disodium arsenate) were from Sarabhai Chemicals, Bombay, India. The antibiotic disks were from Span Diagnostics Limited, Bombay, India.

\section{Resistance to metal ions}

The method of Novick and Roth (1968) was followed with minor modifications for the determination of MICs of metal ions for $39 \mathrm{E}$. coli isolates; $20-\mu \mathrm{l}$ inocula of an overnight (16-18 h) culture of the test strain were added to tubes of sterile Tryptone Yeast Extract (TYE) broth containing serial dilutions of the metal salts. The tubes were mixed, incubated at $37^{\circ} \mathrm{C}$ for $24 \mathrm{~h}$, and then examined for visual turbidity. The lowest concentration of the metal salt at which growth was inhibited (indicated by lack of turbidity) was taken as the MIC. A loopful from each tube with no turbidity was subcultured on to nutrient-agar plates to determine bacteriostatic and bactericidal concentrations. 


\section{Antibiotic susceptibility}

The antibiotic resistance of 39 isolates was determined by Stokes' (1975) method with the following disks; ampicillin $10 \mu \mathrm{g}$; chloramphenicol $30 \mu \mathrm{g}$, tetracycline $30 \mu \mathrm{g}$, co-trimoxazole $1.25 \mu \mathrm{g}$, kanamycin $30 \mu \mathrm{g}$, gentamicin $10 \mu \mathrm{g}$, gabromycin $60 \mu \mathrm{g}$, cephalothin $30 \mu \mathrm{g}$, nalidixic acid $30 \mu \mathrm{g}$, furazolidone $100 \mu \mathrm{g}$, neomycin $30 \mu \mathrm{g}$ and streptomycin $50 \mu \mathrm{g}$.

\section{Results}

In tests with cadmium sulphate and mercuric chloride, a clear difference was observed between very sensitive (MIC $<20 \mathrm{mg} / \mathrm{L}$ ) and very resistant (MIC $>80 \mathrm{mg} / \mathrm{L}$ ) strains, although some strains were moderately resistant (MIC $40-70 \mathrm{mg} / \mathrm{L}$ ) (fig. 1). However, the demarcation was less apparent with silver nitrate and disodium arsenate. A tailing off (plateau effect) was observed among

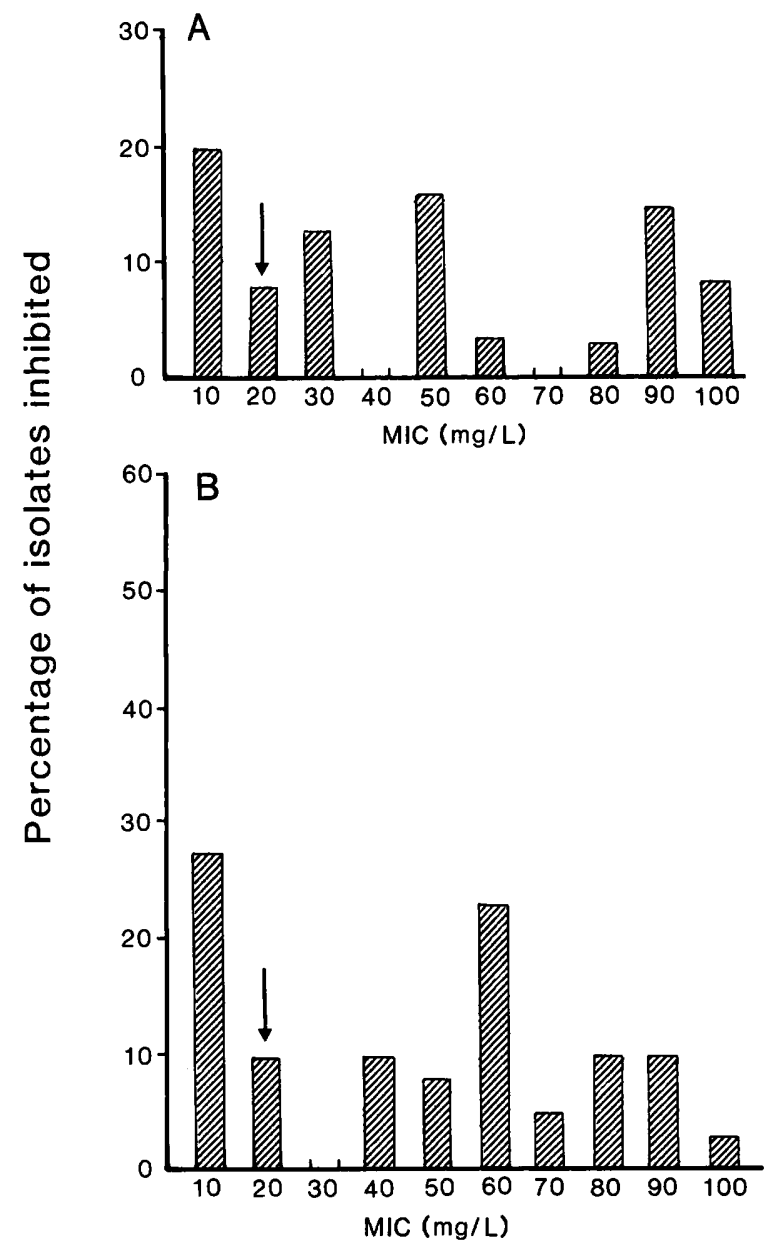

strains very resistant to disodium arsenate (MIC $40000 \mathrm{mg} / \mathrm{L}$ ) and two peaks were observed with strains moderately resistant to silver nitrate (MIC 20-70 mg/L) (fig. 1). Of the $39 \mathrm{E}$. coli isolates tested, $94.9 \%, 76.9 \%, 71.8 \%$ and $61.5 \%$ were resistant to cadmium, arsenate, silver and mercury respectively, and $17.9 \%, 35.9 \%$ and $38.5 \%$ were resistant to two, three and four metals respectively (table I).

In antibiotic susceptibility tests with 39 isolates $48.7 \%$ were resistant to ampicillin, $41 \%$ to cephalothin, $15.4 \%$ to kanamycin, $7.7 \%$ to tetracycline and $2.6 \%$ to co-trimoxazole (fig. 2); $13 \%$ of the isolates were resistant to three or more antibiotics. Of the 23 isolates resistant to antibiotics, particularly to kanamycin, cephalothin or ampicillin, 59\% were also resistant to cadmium sulphate. Strains resistant to tetracyline were also resistant to mercury and arsenate. The strains resistant to kanamycin were resistant to silver as well as to cadmium (table II).
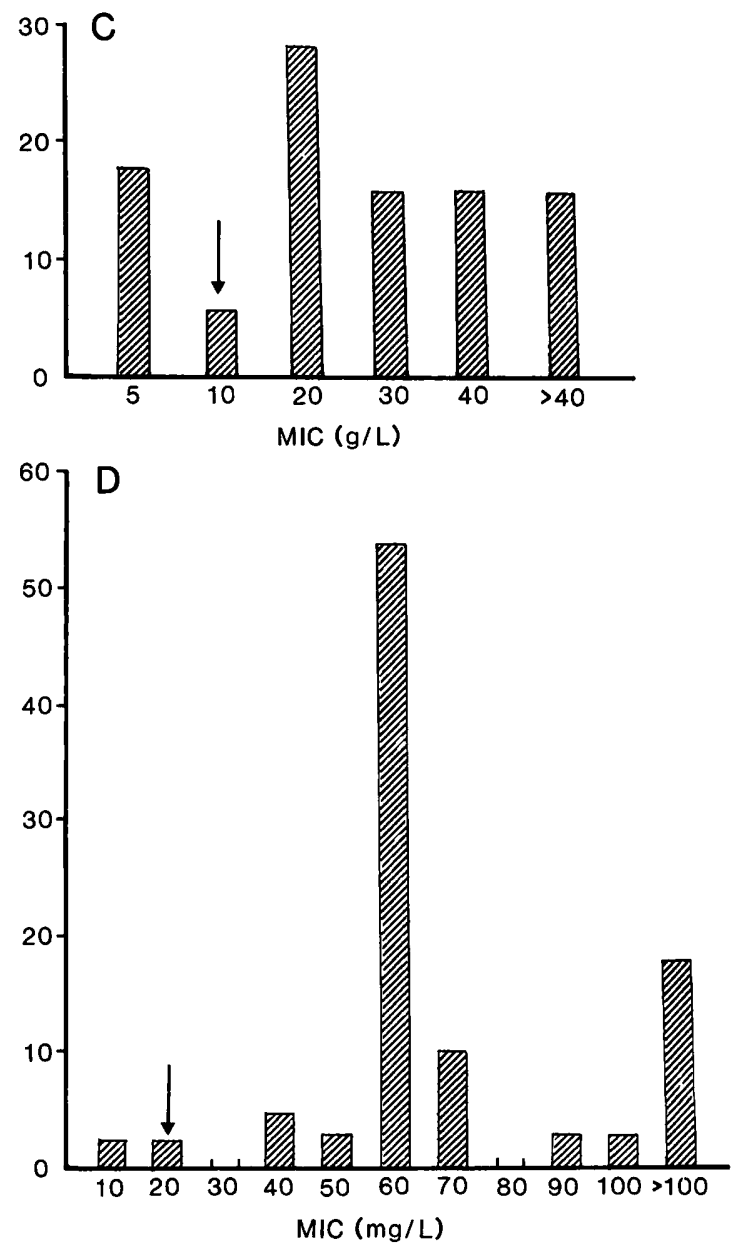

Fig. 1. MICs of (A) silver nitrate (B) mercuric chloride (D) cadmium sulphate and (C) disodium arsenate for 39 food isolates of E. coli. Arrows indicate concentrations above which isolates were considered to be resistant. 
Table I. Metal ion and antibiotic resistance patterns of $E$. coli isolates from foods

\begin{tabular}{|c|c|c|c|c|}
\hline \multirow[b]{2}{*}{$\begin{array}{l}\text { Number of } \\
\text { metal ions or } \\
\text { antibiotics }\end{array}$} & \multicolumn{2}{|c|}{ Metal ion resistance } & \multicolumn{2}{|c|}{ Antibiotic resistance } \\
\hline & $\begin{array}{l}\text { Number }(\%) \\
\text { of resistant } \\
\text { isolates }\end{array}$ & $\begin{array}{c}\text { Resistance } \\
\text { patterns } \\
\text { (number of isolates) }\end{array}$ & $\begin{array}{l}\text { Number }(\%) \\
\text { of resistant } \\
\text { isolates }\end{array}$ & $\begin{array}{c}\text { Resistance } \\
\text { patterns } \\
\text { (numer of isolates) }\end{array}$ \\
\hline 1 & $3(7 \cdot 7)$ & $\mathrm{Cd}(3)$ & $7(30 \cdot 4)$ & $A(3), K(3), C p(1)$ \\
\hline 2 & $7(17 \cdot 9)$ & $\begin{array}{l}\mathrm{Cd} \operatorname{As}(4), \operatorname{Ag~Cd}(1) \\
\operatorname{Ag~As}(1), \mathrm{Hg} \mathrm{As}(1)\end{array}$ & $11(47 \cdot 8)$ & A Cp (10), AT (1) \\
\hline 3 & $14(35 \cdot 9)$ & $\begin{array}{l}\mathrm{Ag} \mathrm{Cd} \mathrm{As} \mathrm{(6),} \mathrm{Ag} \mathrm{Hg} \mathrm{Cd}(5), \\
\operatorname{Hg} C d \mathrm{As}(3)\end{array}$ & $4(17 \cdot 4)$ & $\operatorname{ATCp}(2), \operatorname{AKCp}(2)$ \\
\hline 4 & $15(38 \cdot 5)$ & $\mathrm{Ag} \mathrm{Hg} \mathrm{Cd} \mathrm{As} \mathrm{(15)}$ & $1(4 \cdot 35)$ & A Co KCp (1) \\
\hline
\end{tabular}

$\mathrm{Ag}$, silver nitrate; $\mathrm{Hg}$, mercuric chloride; $\mathrm{Cd}$, cadmium sulphate; As, disodium arsenate; $\mathrm{A}$, ampicillin; $\mathrm{K}$, kanamycin; $\mathrm{Cp}$, cephalothin; $\mathrm{T}$, tetracycline; Co, co-trimoxazole.

\section{Discussion}

The frequency of resistance to metal ions and antibiotics in $E$. coli isolates from various milkbased food samples probably reflects the degree of environmental contamination with these substances and may be related to exposure of bacteria to them (Aiking et al., 1984; Russell and Gould, 1988). Human infections with antibiotic-resistant micro-organisms make treatment difficult by limiting the choice of antibiotics (Al-Jebouri and AlMeshhadani, 1985). Therefore, any source of antibiotic-resistant or metal-ion-resistant microorganisms must be viewed with concern, and the presence in these food samples of $E$. coli with multiple resistance to both antibiotics and metals may present a potential health hazard to the consumer. A similar degree of resistance in Klebsi-

Table II. Correlation between antibiotic and metal ion resistance of $E$. coli isolates from foods

\begin{tabular}{lcrrrr}
\hline & $\begin{array}{c}\text { Number of } \\
\text { resistant } \\
\text { isolates } \\
(23)^{*}\end{array}$ & \multicolumn{4}{c}{ Number resistant to metal ion } \\
\cline { 3 - 6 } Antibiotic & $\begin{array}{c}\mathrm{Ag} \\
(28) \dagger\end{array}$ & $\begin{array}{c}\mathrm{Hg} \\
(24)\end{array}$ & $\begin{array}{c}\mathrm{Cd} \\
(37)\end{array}$ & $\begin{array}{c}\mathrm{As} \\
(30)\end{array}$ \\
\hline $\mathrm{A}$ & 19 & 14 & 14 & 18 & 16 \\
$\mathrm{~T}$ & 3 & 1 & 3 & 2 & 3 \\
Co & 1 & 1 & 0 & 1 & 1 \\
$\mathrm{~K}$ & 6 & 6 & 3 & 6 & 4 \\
$\mathrm{Cp}$ & 16 & 12 & 10 & 15 & 12 \\
\hline
\end{tabular}

* Sixteen isolates were susceptible to the antibiotics tested.

$\dagger$ Numbers in parentheses are total number of isolates resistant to respective metal ion.

For abbreviations, see footnote to table I. ella pneumoniae isolated from foodstuffs has recently been reported (Kaur et al., 1988). The finding of coresistance to metal ions and antibiotics contrasts with an earlier report of Hinton et al. (1986) in which higher proportions of antibiotic-resistant enteric organisms had been isolated from pigs.

Correlation between resistance to metal ions and antibiotics has been reported in bacterial species from different origins (Summers et al., 1978; Cenci et al., 1982; Porter et al., 1982). Some correlation between antibiotic resistance and cadmium resistance was also seen in our study (table II). However, this study provides no evidence for the co-transferability of antibiotic and metal ion resistance because only $59 \%$ of the strains were resistant to antibiotics whereas all were resistant to metal ions.

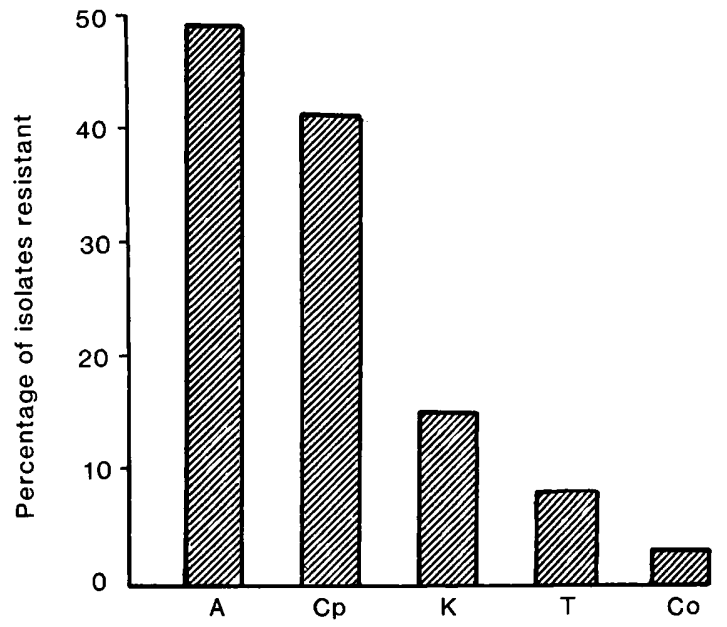

Fig. 2. Incidence of antibiotic resistance in $E$. coli food isolates$\mathrm{A}$, ampicillin; $\mathrm{Cp}$, cephalothin; K, kanamycin; $\mathrm{T}$, tetracycline; Co, co-trimoxazole. 


\section{REFERENCES}

Aiking H, Stijnman A, Van Garderen C, Van Heerikhuizen $H$, Van't Riet J 1984 Inorganic phosphate accumulation and cadmium detoxification in Klebsiella aerogenes NCTC 418 growing in continuous culture. Applied and Environmental Microbiology 47: 374-377.

Al-Jebouri MM, Al-Meshhadani NS 1985 A note on antibioticresistant Escherichia coli in adult man, raw sewage and sewage-polluted River Tigris in Monsul, Nineva. Journal of Applied Bacteriology 59: 513-518.

Anderson ES 1965 Origin of transferable drug-resistance factors in the Enterobacteriaceae. British Medical Journal 2: 12891291.

Antai SP 1987 Incidence of Staphylococcus aureus, coliforms and antibiotic-resistant strains of Escherichia coli in rural water supplies in Port Harcourt. Journal of Applied Bacteriology 62: $371-375$.

Cenci G, Morozzi G, Scazzocchio F, Morosi A 1982 Antibiotic and metal resistance of Escherichia coli isolates from different environmental sources. Zentralblatt für Bakteriologil und Hygiene 1. Abteilung Originale C 3: 440-449.

Chopra I 1982 Microbial resistance to non-antibiotic antimicrobial agents: plasmids and bacterial resistance. In: Russell AD et al. (eds) Principles and practice of disinfection, preservation and sterilisation. Blackwell Scientific Publications, Oxford and London, pp 199-206.

Echeverria P, Murphy JR 1980 Enterotoxigenic Escherichia coli carrying plasmids coding for antibiotic resistance and enterotoxin production. Journal of Infectious Diseases 142: 273-278.

Efstathiou JD, McKay LL 1977 Inorganic salts resistance associated with a lactose-fermenting plasmid in Streptococcus lactis. Journal of Bacteriology 130: 257-265.

Foster TJ, Nakahara H, Weiss AA, Silver S 1979 Transposon A-generated mutations in the mercuric resistant genes of plasmid R 100-1. Journal of Bacteriology 140: 167-181.

Foster TJ 1983 Plasmid-determined resistance to antimicrobial drugs and toxic metal ions in bacteria. Microbiological Reviews 47: 361-409.

Grabow WOK, Progesky OW, Burger JS 1975 Behaviour in a river and dam of coliform bacteria with transferable or nontransferable drug resistance. Water Research 9: 777-782.

Hinton M, Kaukas A, Linton AH 1986 The ecology of drug resistance in enteric bacteria. Society for Applied Bacteriology Symposium Series 15: 77S-92S.

Hugo WB, Russell AD 1982 Types of antimicrobial agents. In: Russell AD et al. (eds) Principles and practice of disinfection, preservation and sterilisation. Blackwell Scientific Publications, Oxford and London, pp 8-106.

Kaur J, Kaul M, Chhibber S 1988 Enterotoxigenicity, klebocinogeny and antibiotic resistance pattern of food isolates of Klebsiella pneumoniae. Folia Microbiology 33: 500-506.
Lee JÁ, Kean BH 1978 International conference on diarrhea of travellers-new directions in research : a summary. Journal of Infectious Diseases 137: 355-369.

Linton AH, Timoney JF, Hinton M 1981 The ecology of chloramphenicol-resistance in Salmonella typhimurium and Escherichia coli in calves with salmonella infection. Journal of Applied Bacteriology 50: 115-129.

Linton AH, Hinton MH 1988 Enterobacteriaceae associated with animals in health and disease. Society for Applied Bacteriology Symposium Series 17: 71S-85S.

Meckes MC 1982 Effects of UV light disinfection on antibioticresistant coliforms in wastewater effluents. Applied and Environmental Microbiology 43: 371-377.

Novick RP, Roth C 1968 Plasmid-linked resistance to inorganic salts in Staphylococcus aureus. Journal of Bacteriology 95 : 1335-1342.

Ørskov R 1984 Genus: Escherichia. In: Krieg NR, Holt JG (eds) Bergey's Manual of systematic bacteriology. Williams and Wilkins, Baltimore, pp 420-423.

Platt DJ, Sommerville JS, Kraft CA, Timbury MC 1984 Antimicrobial resistance and the ecology of Escherichia coli plasmids. Journal of Hygiene 93: 181-188.

Porter FD, Silver S, Ong C, Nakahara H 1982 Selection of mercurial resistance in hospital settings. Antimicrobial Agents and Chemotherapy 22, 852-858.

Russell AD 1982 Modification of the bacteria cell envelope and enhancement of antibiotic susceptibility. In: Stuart-Harris $\mathrm{CH}$, Harris DM (eds) The control of antibiotic-resistant bacteria. Academic Press, London, pp 119-165.

Russell AD, Gould GW 1988 Resistance of Enterobacteriaceae to preservatives and disinfectants. Society for Applied Bacteriology Symposium Series 17: 167S-195S.

Sack RB, Gorbach SL, Banwell JG, Jacobs B, Chatterjee BD, Mitra RC 1971 Enterotoxigenic Escherichia coli isolated from patients with severe cholera-like disease. Journal of Infectious Diseases 123: 378-385.

Starodub ME, Trevors JT 1989 Silver resistance in Escherichia coli R1. Journal of Medical Microbiology 29: 101-110.

Stokes EJ 1975 Clinical bacteriology, 4th edn. Edward Arnold, London, pp 216-217.

Summers AO, Jacoby GA, Swartz MN, McHugh G, Sutton L 1978 Metal cation and oxyanion resistances in plasmids of gram-negative bacteria. In: Schlessinger D (ed) Microbiology. American Society for Microbiology, Washington, DC, pp 128-131.

Towner KJ 1982 Resistance to trimethoprim among urinary tract isolates in United Kingdom. Reviews of Infectious Diseases 4: 456-460.

Walton JR 1977 The relationship between the transferability of enterotoxin plasmids and the simultaneous transfer of antibiotic resistance plasmids. Zentralblatt fur Veterinaermedizin 24B : 317-324. 